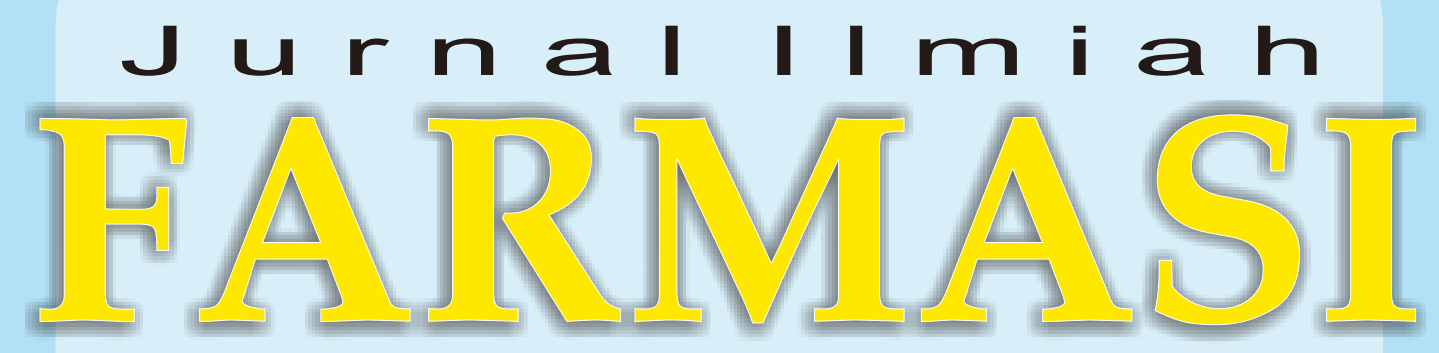

(Scientific Journal of Pharmacy) 
JURNAL ILMIAH FARMASI

(SCIENTIFIC JOURNAL OF PHARMACY)

PIMPINAN UMUM/ PENANGGUNG JAWAB

Dekan Fakultas Matematika dan Ilmu Pengetahuan Alam

Universitas Islam Indonesia

WAKIL PIMPINAN UMUM/ WAKIL PENANGGUNG JAWAB

Ketua Jurusan Farmasi FMIPA UII

\section{MITRA BESTARI}

1. Prof. Dr. Wiryatun Lestariana, Apt

2. Prof. Dr. Zullies Ikawati, Apt

3. Prof. Dr. Sudibyo Martono, Apt

4. Dr. Tedjo Yuwono, Apt

5. Prof. Dr. Dachriyanus, Apt

6. Prof. dr. Iwan Dwiprahasto, MMedSc, PhD

7. Prof. Dr. Lukman Hakim M.Sc., Apt

8. Prof. Dr. Achmad Fudholi, DEA, Apt

9. Prof. Dr. Ibnu Gholib Gandjar, DEA., Apt

\begin{tabular}{ll} 
& \multicolumn{1}{c}{ DEWAN EDITOR } \\
Ketua & : Saepudin, M.Si., Apt \\
Sekretaris & : Rochmy Istikharah, M.Sc., Apt. \\
Anggota & : Vitarani Dwi Ananda Ningrum, M.Si., Apt \\
& Okti R. Mafruhah, MSc., Apt \\
& Dimas Adhi Pradana, MSc., Apt. \\
& Fithria DA. Suryanegara, MSc., Apt. \\
& Ari Wibowo, S.Farm., Apt \\
& Arba Pramudita Ramadani, MSc., Apt. \\
& Oktavia Indrati, S.Farm., Apt.
\end{tabular}

Penerbit

Jurusan Farmasi Fakultas Matematika dan IImu Pengetahuan Alam Universitas Islam Indonesia

Alamat Penerbit Jurusan Farmasi FMIPA UII

Jl. Kaliurang Km. 14,4 Yogyakarta 55584

Telp. (0274) 896439 ext. 3047

Email: jif@uii.ac.id 


\title{
DIAGNOSIS DINI TOKSOPLASMOSIS KONGENITAL DENGAN PCR CAIRAN AMNION
}

\author{
Umatul Khoiriyah \\ Bagian Parasitologi Fakultas Kedokteran Universitas Islam Indonesia
}

\begin{abstract}
Toxoplasmosis is caused by infection with the protozoan Toxoplasma gondii. Congenital Toxoplasmosis is an infection resulting from the transplasental passage of the parasites from infected mother to the fetus. An acute infection in pregnant women associated with a range of outcomes from subclinical infection to intra uterine death.Early diagnosis is important to make decision, therapy or abortion. At present, prosedur diagnostic of congenital toxoplasmosis uses conventional methode especially serological test,but the conventional methode is time consuming, and has high risk. PCR amniotic fluid is one methode to make dignostic of conegenital toxoplasmosis. This is very sensitif and rapid (24 hours) and safer than serological tes of the fetalblood.PCR can be done from 15 week after gestation.
\end{abstract}

Key word: congenital toxoplasmosis- PCR- amniotic fluid. 